This item was submitted to Loughborough's Research Repository by the author.

Items in Figshare are protected by copyright, with all rights reserved, unless otherwise indicated.

\title{
Photovoltaic metering configurations, feed-in tariffs and the variable effective electricity prices that result
}

PLEASE CITE THE PUBLISHED VERSION

http://dx.doi.org/10.1049/iet-rpg.2012.0268

\section{PUBLISHER}

(c) Institution of Engineering and Technology

VERSION

AM (Accepted Manuscript)

LICENCE

CC BY-NC-ND 4.0

\section{REPOSITORY RECORD}

McKenna, Eoghan, and Murray Thomson. 2019. "Photovoltaic Metering Configurations, Feed-in Tariffs and the Variable Effective Electricity Prices That Result”. figshare. https://hdl.handle.net/2134/12618. 
This item was submitted to Loughborough's Institutional Repository (https://dspace.lboro.ac.uk/) by the author and is made available under the following Creative Commons Licence conditions.

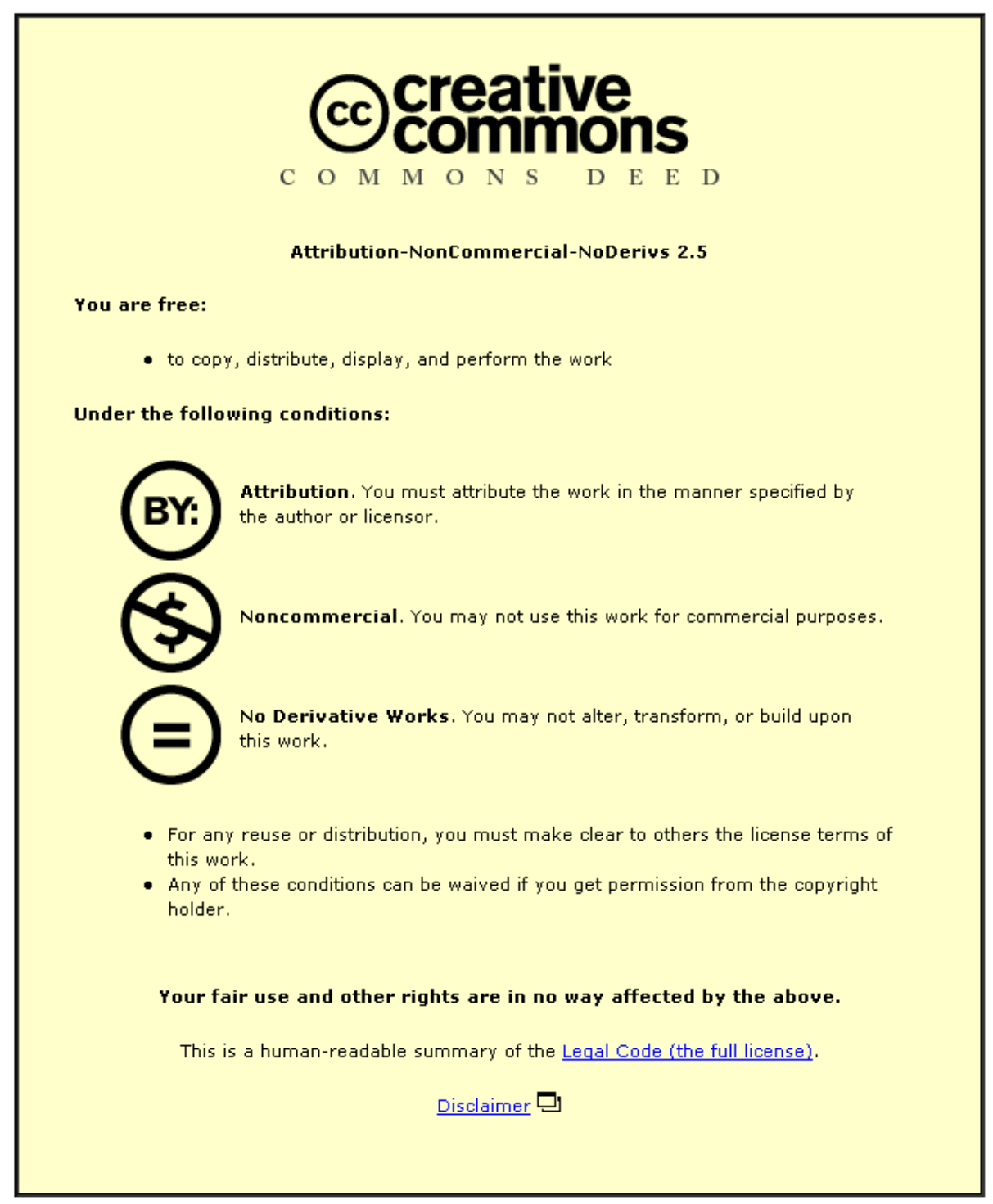

For the full text of this licence, please go to: http://creativecommons.org/licenses/by-nc-nd/2.5/ 